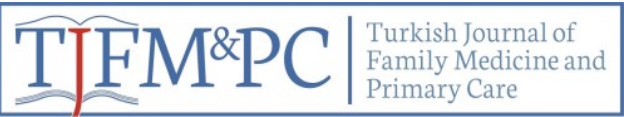

Original Research / Özgün Araştırma

\title{
Periodic Health Examination Knowledge, Attitudes and Behavior among Primary Care Physicians: A Descriptive Study of Preventive Care in Turkey
}

Birinci Basamak Hekimlerinin Periyodik Sağlık Muayenesi Hakkındaki Bilgi, Tutum ve Davranışları: Türkiye'deki Koruyucu Bakıma Yönelik Tanımlayıcı Bir Çalışma

Fisun Sözen ${ }^{* 1}$, Sinem Aydemir ${ }^{2}$, Altuğ Kut ${ }^{3}$, Zeliha Özbakır ${ }^{4}$, Gökhan Eminsoy ${ }^{l}$

\begin{abstract}
Aim: Primary care physicians play an important role in providing the services of health counseling, and early disease diagnosis. This study aims to reveal the practice status of periodic health examinations (PHE), influencing factors and primary care clinicians' knowledge, attitudes and behavior about PHE in Turkey. Materials-Methods: The study was conducted between December 2014 and April 2015 with the participation of 629 family medicine specialists and general practitioners, randomly selected through stratified sampling from all 7 geographical regions in Turkey. Physicians were asked to answer the questionnaire on a face to face manner (response rate \%100). Besides 17 questions on socio-demographic items and specifications of PHE, the questionnaire consists of 12 questions including 4 knowledge, 4 attitudes, 2 behavior, and 2 questions on preferences. Results: Of the respondents $19.4 \%$ were specialists, and $55.3 \%$ of all physicians applied PHE periodically. However, $68.4 \%$ of respondents stated that PHEs are insufficiently applied in primary care and $\% 37$ think that the rates of PHEs would increase when registered patient population per physician would decrease. Specialists were significantly more applying PHE and had significantly more correct answers regarding knowledge, attitude and behavior questions $(\mathrm{p}<0.05)$. Physicians working in regions with higher socioeconomic levels had significantly more correct answers regarding knowledge about PHE $(\mathrm{p}<0.001)$. However, attitude and behavior levels on PHE in socioeconomically compromised regions like South-Eastern Anatolia and Black Sea Region were significantly lower $(\mathrm{p}<0.001)$. Our study suggests that special training on PHE does not play a decisive role in using PHE in daily practice $(\mathrm{p}>0.05)$.

Key words: Primary health care, preventive medicine, periodic health examination, family medicine,
\end{abstract} family medicine specialist, early diagnosis

\section{ÖZET}

Amaç: Aile hekimleri sağlık danışmanlığı, hastalıkların erken tanısı ve birinci basamak sağlık hizmetlerinin etkili sunulmasında önemli bir yere sahiptir. Bu çalışmanın amacı birinci basamak sağlık hizmetlerinde Periyodik Sağlık Muayenelerinin (PSM) uygulanma durumu ve etkileyen faktörler ile PSM hakkında birinci basamak klinisyenlerinin bilgi, tutum ve davranışlarının belirlenmesidir. Gereç-Yöntem: Tanımlayıcı tipteki bu çalışma Aralık 2014 ile Nisan 2015 arasında Türkiye Cumhuriyeti'ni temsil eden 7 coğrafi bölgeden tabakalı örneklem yöntemi ile belirlenen 629 aile hekimliği uzmanı ve aile hekimliği sertifikalı pratisyen hekimin katılımıyla yürütülmüştür. Aile hekimlerinden anketi yüz yüze cevaplamaları istenmiştir (katılım oranı \%100). Sosyodemografik öğeler ve PSM'nin özellikleri hakkındaki 17 soru dışında, anket 4 bilgi, 4 tutum, 2 davranış ve 2 soru da tercihlerle ilgili olmak üzere 12 sorudan oluşmaktadır. Bulgular: Katılımcıların \%19,4’ü aile hekimliği uzmanıdır ve tüm aile hekimlerinin \%55,3’ü periyodik olarak PSM yapmaktadır. Bununla birlikte, katılımciları\%68,4'ü birinci basamakta PSM'lerin yetersiz uygulandığını ve \%37'si de doktor başına kayıtlı hasta popülasyonu azaltıldığında PSM oranlarının artacağını düşündüğünü belirtmiştir. Uzmanlar PSM'yi önemli ölçüde daha fazla uyguluyorlardı ve bilgi, tutum ve davranış sorularına önemli ölçüde daha doğru cevap vermişlerdir $(\mathrm{p}<0.05)$. Sosyoekonomik düzeyi daha yüksek olan bölgelerde çalışan hekimlerin PSM konusunda bilgi ile ilgili sorulara daha doğru cevap vermiş̧lerdir $(\mathrm{p}<0.001)$. Ancak, Güneydoğu Anadolu ve Karadeniz Bölgesi gibi sosyoekonomik açıdan düşük bölgelerde PSM'ye yönelik tutum ve davranış düzeyleri anlamlı derecede düşüktür $(\mathrm{p}<0.001)$. Çalışmamız PSM konusunda özel eğitimlerin günlük pratikte PSM uygulamasında belirleyici bir rol oynamadığını düşündürmektedir ( $>>0.05)$.

Anahtar kelimeler: Temel sağlı hizmeti, koruyucu hekimlik, periyodik sağlık muayenesi, aile hekimliği, aile hekimliği uzmanlığı, erken tanı

Received date / Geliş tarihi: 20.05.2019, Accepted date/ Kabul tarihi: 13.09.2019

${ }^{1}$ Baskent University Faculty of Medicine, Department Family Medicine

${ }^{2}$ Kulu Tavsancali Aile Sagligi Merkezi

${ }^{3}$ Baskent University Faculty of Medicine, Department Family Medicine

${ }^{4}$ Altındag Yunus Emre Aile Sagligi Merkezi

*Address for Correspondence / Yazışma Adresi: Fisun SOZEN, Baskent University Faculty of Medicine, Department Family Medicine, Fevzi Çakmak Cad. 10. Sok. No: 4506490 Bahcelievler - Ankara/TURKEY

E-mail: fisunsozen@gmail.com

Sozen F, Aydemir Sinem, Kut A, Ozbakır Z, Eminsoy G. Periodic Health Examination Knowledge, Attitudes and Behavior among Primary Care Physicians: A Descriptive Study of Preventive Care in Turkey.TJFMPC, 2019; 13(4): 418-426.

DOI: $10.21763 /$ tjfmpc.634371 


\section{INTRODUCTION}

The aim of Periodic health examination (PHE) is to reduce morbidity and mortality by identifying risk factors and early symptoms of curable diseases of asymptomatic people. ${ }^{1-3}$ Today some of the most comprehensive evidence-based screening guidelines were designed by The Canadian Task Force on Preventive Health Care (CTFPHC) in 1976, and the U.S. Preventive Services Task Force (USPSTF) in 1984. ${ }^{4-2}$ The Turkish Ministry of Health start working on PHE in 2011 and finalized its efforts with the publication of the "Guide for Periodic Health Examinations and Scanning Tests Recommended in the Primary Care Practice" in 2015. ${ }^{5}$

Authorities emphasized, that every medical discipline should contribute to determining the format of PHE. However, primary care physicians should certainly take place in applying PHE in terms of comprehensiveness and interdisciplinary form of the profession in conducting and guiding the process. $^{2}$ The yearly per capita application to primary care physicians in Turkey is reported to be $2.9 .^{6-7}$ Therefore, primary care physicians are obtaining important opportunities for health counseling and early diagnosis of peoples' diseases. $^{8-9}$

The present study aims to reveal the practice status of PHE within the practice of primary healthcare services, and primary clinicians' knowledge, attitudes, and behavior about influencing factors.

\section{MATERIALS and METHODS}

The primary care system in Turkey consists of both general practitioners and family medicine specialists (FMS). FMSs achieve this title after completing a three-year residency program after medical school. The "Nonspecialists" (NS) are Practitioners who only have taken short-term orientation training in family medicine. The NSs are the major providers of primary care in Turkey. ${ }^{10}$

FMSs and NSs from all seven geographical regions in Turkey participated voluntarily as subjects in this descriptive study. Recent figures indicate that there is a universe of 21000 primary care physicians in Turkey. The study group was identified through stratified sampling using 50\% unknown frequency, 95\% confidence interval and 5\% deviation. Accordingly, we needed 629 physicians, who gave their signed informed consent to form the study group.

We used a 29-item questionnaire as the data source, of which 17 questions were about socio-demographics and PHE specifications, 10 questions were about knowledge, attitudes and behavior questions, and 2 questions on preferences. Since to our knowledge, there is no structured questionnaire about applying PHE, the researchers created the questionnaire by preparing 10 questions about PHE practice in primary care, comprising four knowledge, four attitude, and two behavior questions. We used two more questions to demonstrate preferred PHEs' and preferred patient education methods. The questionnaire was created by the researchers using literature and presented to the experts in that field for their opinions.

We trained eleven physicians (4 from the Marmara Region, 2 from the Central Anatolia Region, 1 from each of the other regions) to apply the questionnaire from 22.12.2014 to 20.04.2015 through face-to-face interviews. We excluded physicians who are not working in primary care settings, not accepting to join the study, and incompletely filled out the questionnaire. For every excluded physician, another one who was voluntary and working in the same institution was randomly entered the study group.

Data from the research were evaluated with the SPSS program (Statistical Package for Social Sciences for Windows v.22, 0, SPSS Inc. Chicago, IL). Descriptive statistics were presented as mean $( \pm)$ standard deviation, median (min-max), frequency distribution and percentages. Additionally, Chi-square, Yates Corrected Chi-square and Fisher's Exact tests were conducted. The conformance of the variables with normal distribution was examined through visual (histograms and possibility graphs) and analytical ( $\mathrm{n}$ being $\geq 50$, Kolmogorov Smirnov Test; $\mathrm{n}$ being $<50$, Shapiro-Wilk Test) methods. The effects of different predictors on PHE application were assessed by logistic regression analysis. For variables found not conforming to normal distribution, the Mann-Whitney U and Kruskal Wallis tests were performed. The effect of the different predictors on the PHE application status was evaluated through logistic regression analysis by using the possible factors determined on the previous analyses for the multi-variable analysis. The relationship between variables was assessed through 
Spearman's Correlation test. The statistical level of significance was regarded as $\mathrm{p}<0.05$.

This study had been formed as a Medical Doctorate thesis and approved by Başkent University Institutional Review Board and Ethics Committee (Project no: KA14/316) and there was no financial support.

\section{RESULTS}

\section{Descriptive Features}

The mean age was $41.9 \pm 7.8$ years ( 27 min., 66 max.). Of the total $58.2 \%(n=366)$ were male and the male/female ratio was 1.4. Off the total sample $87.6 \% \quad(n=551)$ were married, and $82.5 \%(\mathrm{n}=519)$ had at least one child. FMSs composed $19.4 \%$ of the study group.

\section{PHE Application and Influencing Factors}

Of the participating physicians, 55.3\% $(n=348)$ applied PHE to their patients $(78.7 \%$ of the FMSs, $49.7 \%$ of the NSs). Among PHE applying physicians $30.2 \% \quad(n=105)$ always applied PHE to children and $3.4 \%(n=12)$ to adults; $1.7 \%(\mathrm{n}=6)$ never applied PHE to children and $1.1 \%(\mathrm{n}=4)$ to adults. On the other hand, $10.9 \% \quad(n=38)$ stated that they always applied PHE to elderly persons, while $0.6 \%$ $(n=2)$ did never (Table 1).
Among the total $68.4 \%(n=430)$ think that they insufficiently provide PHE during their practice. However, $43.5 \% \quad(n=187)$ were considering this as a problem and suggesting a solution. They most frequently recommend to "Reduce the number of population assigned and increase the number of family physicians $(37.4 \%, n=70)$ ". The second was to "Provide PHE training to each physician and update this training at certain intervals $(28.3 \%, \mathrm{n}=53)$ ", followed by the third, which was to "Reduce daily work-load (paperwork and accounting duties) and number of night shifts $(16.1 \%$, $\mathrm{n}=30$ )

When we investigate if physicians apply PHE according to whether they are experts or not, we found a significant difference in favor of FMSs $(\mathrm{p}<0.001$; Table 2). However, 9.4\% $(n=59)$ of the total stated that they never had lessons on preventive care, screening tests or PHE during medical training. Besides, 91.8\% $(\mathrm{n}=112)$ of 122 specialists received additional training on preventive care, screening tests and PHE during their residency program $[85.4 \%$ $(n=537) ; \quad 45.6 \% \quad(n=287) ; \quad 37.8 \% \quad(n=238)$ respectively]. Physicians were updating their training using directives and courses of the ministry of health $[57.84 \%(n=364)]$, internet sources $\quad[22.9 \% \quad(n=144)], \quad$ and national/international journal articles and congress sessions $[9.9 \%(n=62)]$. (Table 1$)$

Table 1. Distribution of PHE application status according to gender, specialty and training status, distribution of years spent in the medical profession in total, and in the specialty of family medicine

\begin{tabular}{|c|c|c|c|}
\hline & \multicolumn{2}{|c|}{ PHE Application Status } & \multirow{2}{*}{$\mathbf{p}$} \\
\hline & Performing & Not Performing & \\
\hline \multicolumn{4}{|l|}{ Gender } \\
\hline Man & $205(56.0)$ & $161(44.0)$ & \multirow[t]{2}{*}{0.684} \\
\hline Woman & $143(54.4)$ & $120(45.6)$ & \\
\hline \multicolumn{4}{|l|}{ Specialty status } \\
\hline Family Medicine Specialist & $96(78.7)$ & $26(21.3)$ & \multirow[t]{2}{*}{$<0.001$} \\
\hline Non-Specialist Physician & $252(49.7)$ & $255(50.3)$ & \\
\hline \multicolumn{4}{|c|}{ Trained in preventive medicine, screening tests or PHE during residency $(n=122)$} \\
\hline Trained & $88(78.6)$ & $24(21.4)$ & \multirow[t]{2}{*}{$0.997 *$} \\
\hline Not & $2(20.0)$ & $8(80.0)$ & \\
\hline \multicolumn{4}{|l|}{ Geographical Regions } \\
\hline Mediterranean & $45(73.8)$ & $16(26.2)$ & \multirow[t]{7}{*}{$<0.001$} \\
\hline Eastern Anatolia & $10(31.3)$ & $22(68.8)$ & \\
\hline Aegean & $49(55.7)$ & $39(44.3)$ & \\
\hline Southeastern Anatolia & $52(80.0)$ & $13(20.0)$ & \\
\hline Central Anatolia & $89(74.2)$ & $31(25.8)$ & \\
\hline Marmara & $70(32.3)$ & $147(67.7)$ & \\
\hline Black Sea & $33(71.7)$ & $13(28.3)$ & \\
\hline Years spent in the profession & $17.09 \pm 7.71$ & $16.22 \pm 7.63$ & $0.232 * *$ \\
\hline Years spent in the family medicine practice & $4.78 \pm 1.68$ & $4.53 \pm 1.33$ & $0.073 * *$ \\
\hline \multicolumn{4}{|c|}{$\begin{array}{l}\text { *Fisher's Correct Test } \\
\text { **Mann-Whitney U Test } \\
\text { Continuous variables were presented as "mean } \pm \text { standart deviation". Categorical variables were presented as "number (line } \\
\text { percentage)". }\end{array}$} \\
\hline
\end{tabular}


The distribution of physicians who are applying PHE in different geographical regions in Turkey is shown in Table 1. PHE applications in the Eastern Anatolia and the
Marmara Regions were lower than in other regions (Table 2).

Table 2. Composition of the study group according to regional distribution. Ankara/Turkey 2015

\begin{tabular}{|l|l|l|l|}
\hline \multirow{2}{*}{ Geographical Region } & Family Physicians & N per Layer \\
\cline { 2 - 4 } & Total N & Layer Weight & 61 \\
\hline Mediterranean & 1252 & 0,097 & 32 \\
\hline Eastern Anatolian & 654 & 0,050 & 88 \\
\hline Aegean & 1814 & 0,140 & 65 \\
\hline Southeastern & 1351 & 0,104 & 120 \\
\hline Central Anatolian & 2471 & 0,191 & 217 \\
\hline Marmara & 4472 & 0,345 & 46 \\
\hline Black-Sea & 955 & 0,074 & 629 \\
\hline Total & 12969 & 1 & \\
\hline
\end{tabular}

\section{Level of Knowledge on PHE}

Four questions were asked. The first intended to asses if the subject knows that PHE is described in the definition of Family Medicine. Of the respondents, $27.3 \%(\mathrm{n}=172)$ were aware of the correct answer, of which $57.4 \%(n=70)$ belong to FMSs.

The second question assessed the knowledge about the definition of preventive activity in the application of PHE. Of the respondents, $71.4 \% \quad(\mathrm{n}=449) \quad$ answered correctly and knew that besides primary, secondary and tertiary prevention; primordial prevention doesn't belong to preventive activity, of which $84.4 \%(n=103)$ were FMSs.

The third question assessed the knowledge about the correct definition of PHE, where $75.2 \%(n=473)$ of the total answered correctly, of which $82.8 \% \quad(n=101)$ where FMSs.

The fourth question investigated the knowledge about the specifications of diseases to be taken into a PHE program. Only $21.6 \%$ $(n=136)$ were aware of the correct answer and $43.4 \%(n=53)$ of them were FMSs.

While correct answers to the first three questions were significantly more frequent among FMSs $(\mathrm{p}<0.001, \mathrm{p}=0.001, \mathrm{p}=0.041$ respectively), the fourth question was significantly more frequent among NSs $(\mathrm{p}<0.001)$. There was also a significant difference in the distribution of correct knowledge answers between geographical regions $(p<0.001)$ (Table 3$)$. The post-hoc analysis revealed that the significant difference was between the rates of the South-Eastern Anatolian region and the Aegean, the Black Sea and the Marmara regions $(p<0.001)$ (Table
3). There was no significant difference among those who were trained to apply PHE and those who were not $(p=0.247)$ (Table 3). Correct answers were significantly higher in those who were newer in the medical profession $(\mathrm{p}<0.05)$.

\section{Attitudes towards PHE}

Four questions were asked. The first question analyzed which attitude does not conform to the decision of performing PHE in daily practice. The most frequently chosen incorrect attitude was to perform PHE upon the request of the patient him/herself $(57.2 \%, \mathrm{n}=360)$. Among the correct answers, $68 \%(n=83)$ were FMSs.

The second question assessed the specifications of PHE. The appropriate attitude was to plan PHE upon the specifications of the region of responsibility and clinical observations. Of all respondents $74.7 \%$ $(n=470)$ answered correctly. Off them $86.9 \%$ $(n=106)$ were FMSs.

The third question was about which attitude does not conform with PHE in primary care. The correct attitude was that the primary care clinician should deal with unresolved complaints and has to choose to apply PHE in patients with appropriate medical status. Only $25.3 \%(n=159)$ of the respondents were aware of this correct attitude. Among FMSs 38.5\% $(\mathrm{n}=47)$ choose this answer, while $22.1 \%$ $(n=112)$ of the NSs agreed with the same.

The fourth question evaluated attitudes towards the age groups in which PHE application is not mandatory. The correct answer was that PHE application in 
adolescents and elderly people is not mandatory in clinical practice in Turkey, which was chosen by $60.7 \%(n=382)$.

Correct answers to all four questions were significantly more frequent among FMSs $(\mathrm{p}=0.007, \quad \mathrm{p}=0.001, \quad \mathrm{p}<0.001, \quad \mathrm{p}=0.039$ respectively). The correct attitude towards PHE in the Marmara Region was significantly higher than in other regions $(\mathrm{p}<0.001)$.

In addition, the correct attitude in physicians who had training on preventive medicine, screening tests, and/or PHE applications was significantly higher $(p=0.047)$ (Table 3). Correct answers were significantly higher in those who were newer in the medical profession $(\mathrm{p}<0.05)$.

\section{Behavior about PHE}

Two questions were asked. Firstly, we asked if the physician provides patient-centered training regarding diseases included in the national PHE program. Among the total $61.5 \%$ $(n=387)$ claimed that they do so. However, there was no statistical significance among specialties $(\mathrm{p}=0.100), 68 \%$ of the FMSs and $60 \%$ of the NSs gave correct answers. Those who provide patient training had significantly spent fewer years in the medical profession than those who did not $(16.2 \pm 7.7 ; 17.6 \pm 7.6$ respectively, $\mathrm{p}=0.035$ ).

The second question consisted of some propositions regarding the correct behavior of providing PHE. The correct behavior was to perform PHE to every patient whenever it is possible. This correct behavior was performed by $89.5 \%(n=563)$ of all physicians. However, specialists were demonstrating significantly more correct behaviors compared to NSs [95.1\% $(\mathrm{n}=126), 88.2 \%(\mathrm{n}=447)$ respectively; $\mathrm{p}=0.038]$. Also, physicians with correct behavior in providing PHE in primary care had significantly spent fewer years in the medical profession $\quad(16.36 \pm 7.63, \quad 19.62 \pm 7.54$ respectively, $p=0.001)$, while the years spend in family medicine was not significantly different $(4.66 \pm 1.56,4.77 \pm 1.38$ respectively, $\mathrm{p}=0.243)$.

When analyzing geographical regions; both the first and second question demonstrates that physicians in the Marmara region have more correct behaviors than those in the South-Eastern Anatolian region (71.0\%, $41.5 \%, \quad \mathrm{p}<0.05 ; \quad 94.9 \%, \quad 81.5 \%, \quad \mathrm{p}<0.05$ respectively) (Table 3 ).

\section{Comparison of All Given Answers}

The number of correct answers to the sum of questions in the Marmara Region was significantly higher than in other regions $(p<0.001)$. FMSs gave more correct answers to all types of questions than NSs did $(p<0.001)$ (Table 3). However, while years spent in the medical profession had a significant but weak negative correlation in having correct knowledge, attitudes and behavior towards PHE, years spent in working as a family physician had no significant correlation with given answers (Table 4).

\section{Questions on Patient Training and Preferred PHEs}

The most preferred application of PHE was questioning the use of alcohol/tobacco $(40.9 \%$, $\mathrm{n}=257$ ), followed by assessing family risk factors $(32.1 \%, n=202)$. Lesser chosen alternatives were measurement and follow-up of height/weight $(17.0 \%, \mathrm{n}=107)$, questioning dietary habits $(6.2 \%, \mathrm{n}=39)$, and questioning regular exercise status $(3.8 \%, \mathrm{n}=24)$.

Another question assessed which method of patient training is preferred. We found that $73.9 \% \quad(n=465)$ of all subjects preferred to use a face-to-face method in patient education, while $13.0 \% \quad(n=82)$ use posters/flyers, $\quad 5.7 \% \quad(\mathrm{n}=36) \quad$ use video recordings, and $7.3 \%(n=46)$ preferred to make presentations.

There was no statistical difference among FMSs and NSs regarding the last two questions ( $p=0.070, p>0.05$ respectively).

\section{Effects of Different Predictors on Applying PHE}

We performed a logistic regression analysis to evaluate the effects of different predictors on the ability of family physicians to apply PHE. Being a family medicine specialist increases the ability of applying PHE by four times. All other predictors had little or no effect on applying PHE (Table 5). 
Table 3. Distribution of scores of knowledge, attitudes, and behaviors according to the regions and specialty, training status of the physicians about PHE

\begin{tabular}{|c|c|c|c|c|c|c|c|c|c|c|c|c|}
\hline \multirow{2}{*}{$\begin{array}{l}\begin{array}{l}\text { Distribution of correct } \\
\text { answers }\end{array} \\
\text { anser }\end{array}$} & \multicolumn{3}{|l|}{ Knowledge } & \multicolumn{3}{|l|}{ Attitudes } & \multicolumn{3}{|l|}{ Behavior } & \multicolumn{3}{|l|}{ Total } \\
\hline & Mean \pm SD & $\begin{array}{l}\text { Median } \\
\text { (min-max) }\end{array}$ & $\mathbf{p}$ & Mean \pm SD & $\begin{array}{l}\text { Median } \\
\text { (min-max) }\end{array}$ & $\mathbf{p}$ & Mean \pm SD & \begin{tabular}{|l} 
Median \\
(min-max)
\end{tabular} & $\mathbf{p}$ & Mean \pm SD & $\begin{array}{l}\text { Median } \\
\text { (min-max) }\end{array}$ & $\mathbf{p}$ \\
\hline \multicolumn{13}{|l|}{ Regions } \\
\hline Mediterranean & $1.85 \pm 1.10$ & $2(0-4)$ & \multirow[t]{7}{*}{$<0.001^{\mathrm{a}}$} & $1.70 \pm 0.90$ & $2(0-4)$ & \multirow[t]{7}{*}{$<0.001^{a}$} & $2.25 \pm 0.83$ & $2(0-3)$ & \multirow[t]{7}{*}{$\mathrm{o.003}^{\mathrm{a}}$} & $5.80 \pm 1.91$ & $6(0-10)$ & \multirow[t]{7}{*}{$<$.001 $^{\mathrm{a}}$} \\
\hline Eastern A. & $1.84 \pm 1.16$ & $2(0-4)$ & & $1.88 \pm 0.91$ & $2(0-3)$ & & $2.19 \pm 0.86$ & $2(0-3)$ & & $5.91 \pm 1.44$ & $6(3-8)$ & \\
\hline Aegean & $2.04 \pm 0.99$ & $2(0-4)$ & & $2.25 \pm 1.08$ & $2(0-4)$ & & $2.23 \pm 0.74$ & $2(0-3)$ & & $6.53 \pm 1.97$ & $6(2-11)$ & \\
\hline Souteast A. & $1.51 \pm 1.06$ & $1(0-4)$ & & $1.45 \pm 0.85$ & $1(0-3)$ & & $1.95 \pm 0.94$ & $2(0-3)$ & & $4.91 \pm 1.88$ & $5(1-9)$ & \\
\hline Central A. & $1.94 \pm 0.81$ & $2(0-4)$ & & $1.76 \pm 0.82$ & $2(0-4)$ & & $2.18 \pm 0.79$ & $2(0-3)$ & & $5.88 \pm 1.43$ & $6(3-9)$ & \\
\hline Black-Sea & $2.34 \pm 0.64$ & $2(1-3)$ & & $1.96 \pm 1.12$ & $2(0-4)$ & & $2.06 \pm 0.64$ & $2(1-3)$ & & $6.37 \pm 1.52$ & $6(3-10)$ & \\
\hline Marmara & $2.02 \pm 0.86$ & $2(0-4)$ & & $2.83 \pm 0.68$ & $3(1-4)$ & & $2.41 \pm 0.71$ & $3(1-3)$ & & $7.25 \pm 1.46$ & $7(3-11)$ & \\
\hline \multicolumn{13}{|l|}{ Med Specialty } \\
\hline Specialist & $2.68 \pm 0.93$ & $3(0-4)$ & \multirow[t]{2}{*}{$<0.001^{b}$} & $2.47 \pm 0.99$ & $3(0-4)$ & \multirow[t]{2}{*}{$<0.001^{\text {b }}$} & $2.42 \pm 0.78$ & $3(0-3)$ & \multirow[t]{2}{*}{$0.001^{b}$} & $7.57 \pm 1.97$ & $8(2-11)$ & \multirow[t]{2}{*}{$<\mathbf{0 . 0 0 1}^{\mathrm{b}}$} \\
\hline Non-Specialist & $1.78 \pm 0.85$ & $2(0-4)$ & & $2.11 \pm 0.98$ & $2(0-4)$ & & $2.19 \pm 0.77$ & $2(0-3)$ & & $6.09 \pm 1.62$ & $6(0-10)$ & \\
\hline \multicolumn{13}{|l|}{ Training status } \\
\hline Trained & $1.94 \pm 0.93$ & $2(0-4)$ & \multirow[t]{2}{*}{$0.247^{b}$} & $2.48 \pm 1.02$ & $3(0-4)$ & \multirow[t]{2}{*}{$0.047^{b}$} & $2.26 \pm 0.76$ & $2(0-3)$ & \multirow[t]{2}{*}{$0.110^{\mathrm{b}}$} & $7.58 \pm 1.99$ & $8(2-11)$ & \multirow[t]{2}{*}{$0.842^{\mathrm{b}}$} \\
\hline Not trained & $2.10 \pm 0.99$ & $2(0-4)$ & & $2.30 \pm 0.68$ & $2(1-3)$ & & $2.06 \pm 0.86$ & $2(0-3)$ & & $7.50 \pm 1.84$ & $7.5(4-10)$ & \\
\hline
\end{tabular}


Table 4. Correlation of years spent in the medical profession and years working as a family physician in giving correct answers to knowledge attitude and behavior questions

\begin{tabular}{|l|l|l|l|l|}
\hline & Years spent in the medical profession & \multicolumn{1}{l|}{ Years working as a family physician } \\
\cline { 2 - 5 } & $\mathbf{r}$ & $\mathbf{p}$ & $\mathbf{r}$ & $\mathbf{p}$ \\
\hline Knowledge & $-0,147$ & $<\mathbf{0 , 0 0 1}$ & $-0,009$ & 0,829 \\
\hline Attitude & $-0,211$ & $<\mathbf{0 , 0 0 1}$ & $-0,082$ & 0,054 \\
\hline Behavior & $-0,095$ & $\mathbf{0 , 0 1 7}$ & 0,056 & 0,162 \\
\hline Total & $-0,228$ & $<\mathbf{0 , 0 0 1}$ & $-0,024$ & 0,543 \\
\hline *Spearman correlation coefficient &
\end{tabular}

Table 5. Logistic regression analysis to evaluate the effects of different predictors on the ability of family physicians to apply PHE to patients

\begin{tabular}{|c|c|c|c|c|c|}
\hline & B (SEM*) & sd & $\operatorname{Exp}(B)$ & \%95 CI** & p \\
\hline $\begin{array}{l}\text { Gender } \\
\text { (Female by Male) }\end{array}$ & $-0.005(189)$ & 1 & 0.995 & $0.688-1.441$ & 0.980 \\
\hline Marital Status $^{1}$ & $0.091(0.367)$ & 1 & 1.095 & $0.534-2.248$ & 0.804 \\
\hline Child Status $^{2}$ & $-0.142(0.327)$ & 1 & 0.867 & $0.457-1.645$ & 0.663 \\
\hline Status of Speciality $^{3}$ & $1.461(0.269)$ & 1 & 4.308 & $2.545-7.293$ & $<0.001$ \\
\hline $\begin{array}{l}\text { Years spent in the Medical } \\
\text { Profession }\end{array}$ & $-0.016(0.015)$ & 1 & 0.985 & $0.956-1.014$ & 0.304 \\
\hline $\begin{array}{l}\begin{array}{l}\text { Years Working as a } \\
\text { physician }\end{array} \\
\end{array}$ & $0.056(0.078)$ & 1 & 1.057 & $0.907-1.232$ & 0.476 \\
\hline $\begin{array}{l}\text { Status of the physician in getting } \\
\text { trained about PHE, screening tests } \\
\text { and preventive medicine }\end{array}$ & $0.353(0.313)$ & 1 & 1.423 & $0.771-2.626$ & 0.259 \\
\hline Eastern Anatolia Region ${ }^{5}$ & $-1.998(0.511)$ & 1 & 0.136 & $0.050-1.113$ & 0.213 \\
\hline Aegean Region ${ }^{5}$ & $-0.895(0.383)$ & 1 & 0.408 & $0.193-1.278$ & 0.190 \\
\hline South-Eastern Anatolia Region ${ }^{5}$ & $0.156(0.447)$ & 1 & 1.168 & $0.486-2.808$ & 0.728 \\
\hline Central Anatolian Region ${ }^{5}$ & $0.053(0.372)$ & 1 & 1.054 & $0.509-2.186$ & 0.887 \\
\hline Marmara Region $^{5}$ & $-2.086(0.369)$ & 1 & 0.124 & $0.060-1.421$ & 0.109 \\
\hline Black-Sea Region $^{5}$ & $-0.315(0.460)$ & 1 & 0.730 & $0.296-1.798$ & 0.494 \\
\hline
\end{tabular}

\section{DISCUSSION}

PHE is a new concept for the healthcare system in Turkey. Although there are worldwide discussions on the necessity of PHE, it is still considered a cornerstone of medical practice. The Guide of USPSTF, ACPM (American College of Preventive Medicine), CTFPHC, and the guides of WHO say that "periodic examination must be applied to every group of age regularly". ${ }^{11-12-13-14}$

The primary healthcare system in Turkey comprises of 6708 Family Health Centers and 971 Public Health Centers (21,000 family physicians). Of these only, approximately $10 \%$ are trained as FMSs. Each of these physicians is caring for a maximum of 4000 persons (60-70 patients/day). The whole transition of the primary care system in Turkey started in 2005 and was gradually completed in $2010 .{ }^{15}$ However, it took five more years to prepare a guide of PHE. In August 2015 the Public Health Agency of Turkey published the final version of the PHE guide for primary care. $^{5-16}$ The results of this study may be helpful for the health system in Turkey as well as all other countries that are relatively new in the transition of primary care services.

Legislations in Turkey state that applying PHEs are mandatory. ${ }^{6-17-18}$ The stratified sampling method of the present study includes the views of 629 of 21000 practicing primary care physicians in all seven regions of Turkey and allows us to assess the status of the whole country. While the mean application for PHE in different countries are about $14-20 \%$, our results indicate that most of the primary care physicians in our country are regularly applying PHE to their patients $(78.7 \%$ of specialists and $49.7 \%$ of non-specialists)..$^{10-11}$ 
The following question arises when we evaluate this result from a different perspective: Why do $44.7 \%$ of the physicians not apply PHE to their patients, although PHE is mandatory? Is it their preference, or are there several other obstacles such as population density of family health centers, lack of resources, lack of knowledge, or lack of patient demand. We believe that all of these reasons have their parts in the answer to this question.

Our results showed that physicians in our study group are mostly applying PHE to children and elderly persons. This may be because adults and adolescents are significantly lesser applying to primary health services. The number of people over 65 is increasing in our country. While it was $7 \%$ of the population in 2010 , it has risen to $8.2 \%$ in 2015. ${ }^{19}$

A majority of the subjects $(68.4 \%)$ state that primary care facilities are lacking sufficient PHE, scanning and counseling services. These physicians are thinking that this problem might be solved by reducing the number of population assigned to each family health center and by providing physicians with appropriate training. While in the US the mean population per physician is 2000 persons and $14 \%$ of the population have a PHE annually, the mean population assigned to each family health center in Turkey is about 4000 recently and there are no reliable data about the frequency of PHE in primary care. ${ }^{6-10}$

Due to this huge patient load assigned to a physician, they might experience a scarcity of time for taking a detailed patient history, conducting a physical examination or applying PHE. We believe that reducing the size of the assigned population will reduce the workload, and applications such as patient education and PHE will be conducted more widely and regularly.

When the level of knowledge, attitudes, and behaviors is assessed, it is seen that the level of FMSs at the point is higher than that of the NSs. We think that the basic medical training on preventive care, screening tests and PHE during medical school does not suffice and that the difference between specialists and NS is depending on the additional training during the residency program, which $91.8 \%$ of all specialists had received.
The distribution of PHE application demonstrates that there is a significant difference among the seven geographical regions in Turkey, which depends on the low application rates in the Marmara and Eastern Anatolian regions. However, unfortunately, the collected data in this study does not explain why these regions tent to apply lesser PHE. We believe that further investigation will help us to understand the reasons behind this difference.

\section{LIMITATIONS}

Because it was not evaluated whether the physician thought that PSM was a waste of time. We did not know whether they would perform the PSM. This should be seen as the limitation of our study.

\section{CONCLUSION}

Institutions such as USPSTF, ACPM, CTFPHC, and AAFP regard periodic health examinations as an essential part of modern medicine practices, support PHEs and recommend them to be performed under appropriate guidance. The present study revealed that most of the family physicians lacked sufficient knowledge, attitudes, and behavior about PHE. This results from the fact that PHE is new and has just been supported by institutions in our country. Family practice organizations, especially specialty associations, in our country should emphasize the training activities through congresses, workshops, and courses that they hold so that family physicians can be trained for PHE applications and supported through appropriate guidance.

\section{REFERENCES}

1. Yıldız M., Sak Ö., Akpınar E. Practicing Evidence-Based Periodic Health Examinations. Turkiye Klinikleri J FamMed-Special Topics 2013;4(5):13-8.

2. Akdeniz M.,Aşık Z.,Yaman H. Periodic Health Examinations. GeroFam 2010;1(1):69-84.

3. Mazıcıŏlu M., Şafak E.D., Üstünbaş H.B. Historical Developmental Process of Periodic Health Examination. Turkiye Klinikleri J FamMed-Special Topics 2013;4(5):1-4.

4. The periodic health examination. Canadian Task Force on the Periodic Health Examination. CanMedAssocJ;1979;121(9):1193-254. 
5. T.C. Sağlık Bakanlığı Türkiye Halk Sağlığı Kurumu. Aile Hekimliği Uygulamasında Önerilen Periyodik Sağlık Muayeneleri ve Tarama Testleri 2015. Access: URL: http://www.ghs.gov.tr/haberres/30062015. pdf. Date: 20.05.2019. (Guide in Turkish)

6. Günes ED, Yaman H. Transition to family practice in Turkey. J Contin Educ Health Prof. 2008 Spring;28(2):106-12. doi: 10.1002/chp.167.

7. T.C. Sağlık Bakanlığı Sağlık Araştırmaları Genel Müdürlüğü Sağlı İstatistikleri Y1llığ1 2017. Access: URL: https://dosyasb.saglik.gov.tr/Eklenti/3014 7,turkcesiydijiv1pdf.pdf?0. 20.05.2019. (Article in Turkish)

8. Ponka D. The periodic health examination in adults. CMAJ 2014 Nov 4;186(16):1245. doi: 10.1503/cmaj.

9. Mavriplis CA. Should we abandon the periodic health examination?: NO. Can Fam Physician. 2011 Feb;57(2):159-61.

10. Zwar N. Family medicine in the USA - an Australian perspective. Aust Fam Physician. 2010 Jun;39 (6): 360-1.

11. $\underline{\text { Shires DA }}^{1}, \underline{\text { Stange KC, Divine G, Ratliff }}$ $\underline{\mathrm{S}}, \underline{\text { Vashi }}$, Tai-Seale M, et al. Prioritization of evidence-based preventive health services during periodic health examinations. AM J Prev Med 2012;42(2):164-73.

12. U.S. Preventive Services Task Force. The Guide to Clinical Preventive Services, 2014.

https://www.ahrq.gov/sites/default/files/w ysiwyg/professionals/cliniciansproviders/guidelines- recommendations/guide/cpsguide.pdf (Accessed:20/05/2019)

13. American College of Preventive Medicine. Coaching\&Counseling Clinical Reference For Clinicians. https://c.ymcdn.com/sites/www.acpm.org/ resource/resmgr/timetoolsfiles/coachingclinicalreference.pdf (Accessed;20/05/2019)

14. World Health Organization.Global action plan for the prevention and control of NCDs 2013-2020. http://www.who.int/nmh/publications/ncdaction-plan/en/.(Accessed;20/05/2019)

15. Akan H.,Tanrı̈̈ver Ö. Patient Education and Counselling in Periodic Health Examination. Turkiye Klinikleri J FamMed-Special Topics 2013;4(5):49-55

16. Aile Hekimliği Uygulama Yönetmeliği. 25 Mayıs 2010 Tarihli ve 27591 Sayılı Resmi Gazete. Access: URL: http://www.resmigazete.gov.tr/eskiler/201 0/05/20100525-10.htm. Date: 20.05.2019. (Article in Turkish)

17. Yıldız M., Sak Ö., Akpınar E. Practicing Evidence-Based Periodic Health Examinations. Turkiye Klinikleri J FamMed Special Topics 2013;4(5):13-8.

18. Burgut E.,Anber N., Akpınar E., Bozdemir N. Periodic Health Examination. Archive Medical Review Journal 2007; 16:1.

19. Türkiye İstatistik Kurumu. İl, yaş grubu ve cinsiyete göre nüfus 2007-2015. Access: URL:

http://www.tuik.gov.tr/VeriBilgi.do?alt id =1059. Date: 20.05.2019. (Article in Turkish) 